\title{
Tratamiento de la osteomielitis esclerosante difusa con roxitromicina a largo plazo: a propósito de un caso
}

\section{Long-term roxithromycin treatment for diffuse sclerosing osteomyelitis: a case report}

T. Creo Martínez ', C. Salazar Fernández², R. del Rosario Regalado, A. Rollón Mayordomo², Y. Marín Lapeira ${ }^{3}$

Resumen: La osteomielitis esclerosante difusa (OED) es una enfermedad de etiología desconocida, con dificultades para el diagnóstico y tratamiento ya que la literatura existente al respecto es confusa, con un gran desconocimiento respecto a su causa y evolución natural. Existen de dos teorías para explicar su origen:

Infecciosa: difícil de confirmar mediante los datos bacteriológicos.

Hiperplasia ósea derivada de una tendoperiostitis crónica, por una disfunción muscular y hábitos parafuncionales.

Se caracteriza por dolor recurrente y tumefacción hemimandibular, aunque puede presentar otras localizaciones, acompañada habitualmente de trismus, presión y parestesia y adenopatías regionales, cursa de forma episódica.

El tratamiento de la OED es complejo, debido a que se han intentado múltiples terapias sin que ninguna haya dado un resultado satisfactorio a largo plazo.Tras revisar el tema, a propósito de un caso clínico, recomendamos roxitromicina a largo plazo como una línea de tratamiento a tener en cuenta en la OED por la eficacia que viene demostrando y los tolerables efectos secundarios, si bien cada caso debido a la complejidad de la enfermedad debe ser revisado individualmente, pero teniendo en cuenta esta opción terapéutica.

Palabras clave: Osteomielitis crónica difusa; Roxitromicina; Hiperplasia ósea; SAPHO.

Recibido: 29.08 .05

Aceptado: 15.11 .05
Abstract: Diffuse sclerosing osteomyelitis (DSO) is a disease of unknown etiology which is difficult to diagnose and treat as the literature available on the subject is confused, and there is a considerable lack of knowledge with regards to what causes it and its natural evolution. There are two theories explaining its origin.

One suggests an infectious origin, but this is difficult to confirm by means of bacteriological data. The other suggests an osseous hyperplasia origin derived from chronic tendoperiostitis as a result of muscular dysfunction and parafunctional habits. The disease is characterized by recurrent pain and hemimandibular tumefaction, although it can present in other locations. It is accompanied normally by trismus, pressure and paresthesia and regional adenopathy. It has an episodic clinical course.

Treating DSO is complex due to the fact that many therapies have been tried but with no long-term success. After reviewing the subject as a result of a clinical case, we recommend considering roxithromycin in the long term as a line of treatment for DSO in view of its efficacy and its tolerable secondary effects. Needless to say, each case should be reviewed individually given the complexity of the disease, while taking into account this therapeutic option.

Key words: Diffuse sclerosing osteomyelitis; Roxithromycin; Osseous hyperplasia, SAPHO.
1 Médico Residente Servicio Cirugía Oral y Maxilofacial.

2 Médico Adjunto Servicio Cirugía Oral y Maxilofacial.

3 Médico Residente Servicio Radiodiagnóstico.

Hospital Universitario Virgen Macarena, Sevilla, España.
Correspondencia:

Teresa Creo Martínez

C/ Doctor Fedriani 19, 2을

41009 Sevilla, España. 


\section{Introducción}

La osteomielitis esclerosante difusa (OED) es una enfermedad de etiología desconocida, con dificultades para el diagnóstico y tratamiento ya que la literatura existente al respecto es confusa, con un gran desconocimiento respecto a su causa y evolución natural. ${ }^{1}$ Para la mayoría de los autores, ${ }^{2-6}$ existen dos teorías para explicar su origen.

Los hallazgos clínicos y radiológicos sugieren un origen infeccioso, ${ }^{2}$ difícil de confirmar mediante los datos bacteriológicos, ya que no en todos los casos ha sido posible aislar un microorganismo causante, y en los casos en los que ha sido posible aislarlos hay autores ${ }^{2}$ que piensan en una posible contaminación a la hora de tomar la muestra. ${ }^{2}$ Sus defensores abogan por un germen de baja virulencia, que actuaría como desencadenante de un proceso autoinmunológico que daría lugar a las lesiones y clínica características, lo cual se ve justificado por la mejoría del paciente con la administración de corticoides, por el que se esté relacionando la enfermedad en algunos casos con el síndrome SAPHO (sinovitis, acné, pustulosis palmoplantar, hiperostosis, osteitis) y por el que responda (aunque muchas veces de manera temporal) a los tratamientos antibióticos. ${ }^{3-5}$ Aquellos casos en los que el agente causal no es aislado y no responden a la terapia bacteriana, se postula que el proceso se trataría de una hiperplasia ósea derivada de una tendoperiostitis crónica, 6,7 producida por una disfunción muscular y hábitos parafuncionales, y aunque mejora con terapia oclusal y relajantes musculares, los detractores de esta teoría postulan que hay más esclerosis intramedular que periostal, y el tratamiento oclusal tampoco es definitivo, sino que la mayoría de los pacientes terminan recidivando en nuevas crisis.

La enfermedad se caracteriza por dolor recurrente y tumefacción hemimandibular (aunque se puede presentar en otras localizaciones) acompañada habitualmente de trismus, presión, parestesia y adenopatías regionales. ${ }^{8}$ Cursa de forma episódica con intervalos de mejoría de duración variable, e intervalos de exacerbación; suele ser de curso prolongado, incluso se han descritos algunos casos de regresión espontánea. Clínicamente se caracteriza por la ausencia de pus, de formación de fístulas o secuestros óseos, ' (fundamental para el diagnóstico de esta enfermedad) siendo éstas el diagnóstico diferencial con la osteomielitis secundaria. En la radiología no suele observarse nada característico, salvo que presenta lesiones osteoescleróticas (se asocian a áreas de cicatrización), con áreas osteolíticas en sacabocados (que aumentan en los períodos de exacerbación de la enfermedad y disminuyen cuando mejora), y reacción periostal.

Histológicamente, se habla de un estado infeccioso crónico, encontrando fibrosis medular y formación ósea heterotópica, aumento del «turn-over» óseo y aumento de la reabsorción ósea, con formación de hueso «pagetoide», e incluso formación de microabscesos, descrito por Eyrich y cols., ${ }^{3-5}$ que clínicamente nunca se manifiesta como pus. ${ }^{9}$

La propuesta de este estudio es mostrar los beneficios del tratamiento a largo plazo de la roxitromicina en esta compleja enfermedad, a propósito de un caso clínico.

\section{Introduction}

Diffuse sclerosing osteomyelitis (DSO) is a disease of unknown etiology that is difficult to diagnose and treat as the literature available on the matter is confused, and there is a considerable lack of knowledge with regard to its cause and its natural evolution.' For most authors there are two theories for explaining its origin. ${ }^{2-6}$

The clinical and radiological findings suggest and infectious origin, ${ }^{2}$ which is difficult to confirm by means of bacteriological data, as not in all cases has isolating a causative microorganism been possible. And in those cases where this has not been possible there are authors ${ }^{2}$ who believe that the sample has possibly been contaminated when taken. Those defending this support the low level of virulence theory that starts off an autoimmunological process leading to the characteristic lesions and clinical symptoms. This is supported by the improvement shown by patients under corticoid treatment. As a result of this, the disease is related in some cases with the SAPHO syndrome (synovitis, acne, palmoplantar pustulosis, hyperostosis, osteitis) and because of this there is a response (although on many occasions just a temporary response) to antibiotic treatment. ${ }^{3-5}$ It has been postulated that osseous hyperplasia attributed to chronic tendoperiostitis 6,7 is behind those cases in which the causative agent is not isolated, as there is no response to bacterial therapy. This would have been caused by muscular dysfunction and parafunctional habits, and while there is an improvement with occlusal therapy and muscle relaxants, the detractors of this theory postulate that there is more intramedullarly sclerosis than periosteal, and that neither is occlusal treatment definitive as most patients eventually suffer more crises.

The disease is characterized by recurrent pain and hemimandibular tumefaction (although it can present in other locations) and it is accompanied usually by trismus, pressure, paresthesia and regional nodal swelling. 8 The clinical course is episodic with intervals of varied duration during which improvement is seen, and intervals when there is exacerbation. It tends to have a protracted course and there have even been descriptions of cases of spontaneous regression. Clinically it is characterized by an absence of pus, the formation of fistulae or bone sequestra1 (which is fundamental when diagnosing this disease) with these being significant for the differential diagnosis of secondary osteomyelitis. Radiologically nothing that is characteristic is observed, except that osteosclerotic lesions appear (these are associated with healing), with osteolytic «moth-eaten» areas (that increase during periods of exacerbation of the disease and that decrease on improvement), and periosteal reaction.

Histologically chronic infection is described, together with bone marrow fibrosis and heterotopic bone formation, bone turn-over and an increase in bone resorption, pagetoide bone formation, and even the formation of microabscesses as described by Eyrich et al., $3-5$ which never manifests clinically as pus. ${ }^{9}$ 


\section{Caso clínico}

Mujer de raza blanca de 30 años de edad, que acude a nuestras consultas externas en Febrero 2002 por flemones mandibulares de repetición tras exodoncia del 36, resistentes al tratamiento antibiótico convencional (amoxi-clavulámico) el panorex realizado fue compatible con osteítis izquierda (Fig. 1). Se instaura tratamiento con Dalacin 300 mg/8 h y corticoides durante 3 meses. Ante la falta de mejoría en junio 2002 se le realiza biopsia y legrado de la zona, con un resultado anatomopatológico de tejido de granulación gigantocelular, por lo que se continúa con el tratamiento anteriormente mencionado durante otros 6 meses más. Dado que la paciente presenta crisis de recaídas con dolor intenso e inflamaciones en la rama ascendente de la mandíbula izquierda sin colección de pus ni fistulizaciones, en diciembre 2002 se le realiza un nuevo TAC de control siendo el resultado de lesión osteolítica de la cortical externa de la rama mandibular izquierda (Fig. 2) con infiltración de las partes blandas y adenopatías cervicales de $1 \mathrm{~cm}$, por lo que se decide realizar biopsia de la lesión bajo anestesia general y toma de muestras para diferentes estudios microbiológicos. El resultado de la biopsia fue de tejido gigantocelular y los estudios microbiológicos fueron negativos (las tinciones con ZN y PAS, los estudios para anaerobios, aerobios, micobacterias y hongos). La paciente es diagnosticada de Osteomielitis crónica por lo que se le realiza decorticación de rama mandibular izquierda seguida de penicilina G 3 millones de unidades/4 H IV durante 7 días seguida de Cloraxilina 1 gramo/4 h/IV durante $72 \mathrm{H}$. continuando con Penicilina V 500 mg /4 h/VO + orbenin 250 mg/4 h durante 4 meses más. El resultado anatomopatológico de la lesión fue de inflamación crónica granulomatosa epitelioide no necrotizante y fibrosis intersticial. La paciente ha evolucionado clínicamente de forma favorable pero comenzó con trismus leve por lo que se prescribe férula de descarga. En septiembre 2003 comienza con crisis de dolor intenso e inflamación de la rama mandibular derecha, la TAC reveló osteomielitis crónica que afecta a ambas ramas mandibulares con reacción esclerosante en la hemimandibula izq y osteolíticas en la rama derecha por lo que se prescribe, en noviembre 2003 roxitromicina 150 mg/12 h + amenen $30 \mathrm{mg} / 12 \mathrm{~h}$. Tras $1 \mathrm{mes}$ de tratamiento la paciente refiere que ha mejorado mucho la sintomatología, la analítica de control presentó una proteína $\mathrm{C}$ reactiva elevada, metabolismo del calcio of extraction of tooth 36.

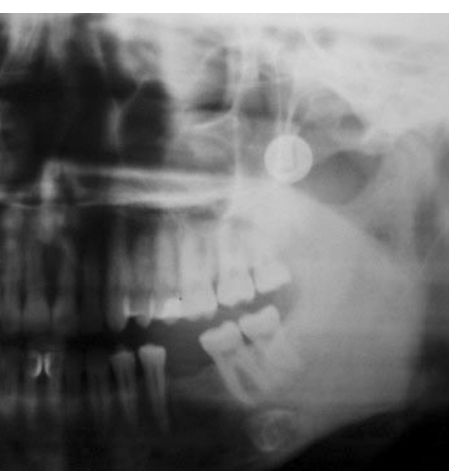

Figura 1. PANOREX: afectación de rama mandibular izq. En lugar Figure 1. PANOREX showing left mandibular ramus affected in area

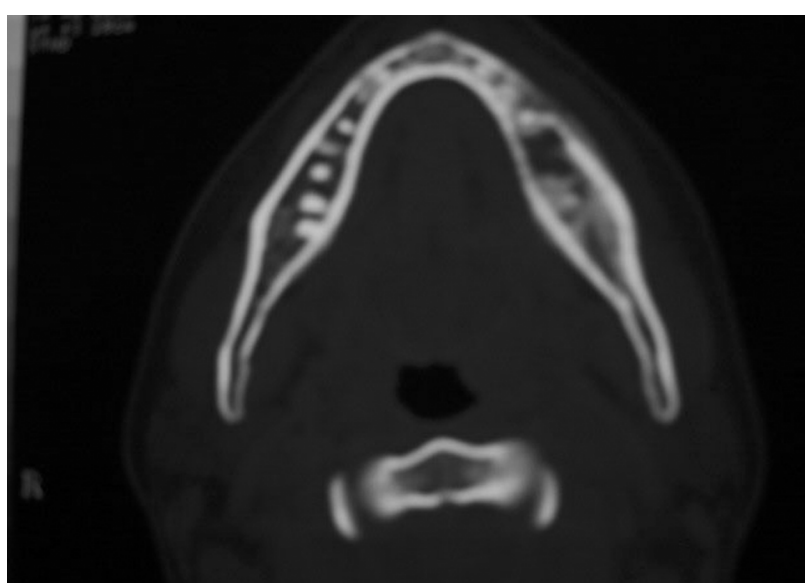

Figura 2. TC: Se aprecia afectación de esponjosa y cortical de rama mandibular izq.

Figure 2. CT scan showing affected spongy and cortical bone in left mandibular ramus.

The purpose of this study is to show the benefits of longterm roxithromycin treatment for this complex disease, as a result of a clinical case.

\section{Clinical case}

White female, 30 years old, attended our Out Patient department in February 2002 as a result of recurrent mandibular suppurative inflammation after removal of tooth 36, resistant to conventional antibiotic treatment (clavulanic amoxi). The panorex carried out was compatible with osteitis of the left side (Fig. 1). Treatment was commenced with Dalacin 300 $\mathrm{mg} / 8 \mathrm{~h}$ and corticoid treatment for three months. As by June 2002 there was no improvement, a biopsy was carried out together with curettage of the area. The anatomopathologic result was of giant cell granuloma tissue, as a result of which the treatment mentioned previously was continued for another six months. Given that the patient was experiencing relapse crises with intense pain and inflammation in the ascending ramus of the left mandible with no pus or fistula formation, in December 2002 a new control CAT scan was carried out. The result indicated an osteolytic lesion in the external cortex of the left mandibular ramus (Fig. 2) with soft tissue infiltration and nodal swelling in the neck of $1 \mathrm{~cm}$. A decision was taken to carry out a biopsy of the lesion under general anesthesia and samples were taken for different microbiological studies. The result of the biopsy was of tissue with giant cells and the microbiological studies were negative (ZN and PAS staining, anaerobic, aerobic, microbacterial and fungal studies). The patient was diagnosed with chronic osteomyelitis and she underwent decortication of the left mandibular ramus followed by the administration of penicillin $G 3$ million units/4 $h$ IV for a week followed by cloxacillin $1 \mathrm{gram} / 4 \mathrm{~h} / \mathrm{IV}$ for 72 hours followed by penicillin $V 500 \mathrm{mg} / 4 \mathrm{~h}$ taken orally, orbenin $250 \mathrm{mg} / 4 \mathrm{~h}$ for another 4 months. The anatomopathologic result of the lesion was of epithelioid nonnecrotizing chronic granulomatous inflammation and interstitial fibrosis. The patient evolved favorably from a clinical 
normal, aumento de LDH y del fósforo y analíticas de control hepático mensual normales. La RNM de control (Fig. 3) presentó alteraciones esclerosantes en rama y cóndilo izquierdo con destrucción de cortical medial y externa compatible con el tratamiento quirúrgico, afectación esclerosante de la rama derecha a nivel de ángulo con irregularidades de la cortical externa e inflamación del masetero y adenopatías bilaterales. En la ganmagrafía ósea (Fig. 4) se ve un aumento leve de la fase vascular supero-externo órbita drcha, malar izq, y rama mandibular dcha, en la fase ósea aumento de malar izq y derecho, y aumento de captación de cóndilo izq. y fémur drcho, que no presenta clínica alguna gracias al tratamiento con roxitromicina.

Se ve a la paciente periódicamente, mejorando mucho la sintomatología, hasta desaparecer el dolor en mandíbula, manifestando sólo dolor frontal, se le hace un SPET de control en mayo 2004, dando como resultado aumento de la captación en fase ósea de frontal izq, y en menor grado del malar dcho y ángulo mandibular dcho, con mejoría de mandíbula y malar izq. Actualmente (Marzo del 2005) la paciente está libre de dolor facial y continúa con el tratamiento con roxitromicina, radiológicamente presenta lesiones esclerosantes en los focos óseos anteriormente referidos pero no nuevos focos osteolíticos. A partir de Marzo la paciente decide suspender el tratamiento porque quiere quedarse embarazada y hasta el momento (mayo del 2005) está asintomática.

\section{Discusión}

El tratamiento de la OED es complejo, debido a que se han intentado múltiples terapias sin que ninguna haya dado un resultado satisfactorio a largo plazo. Mientras que a corto plazo hay terapias que parecen eliminar la sintomatología temporalmente, parece que en muchos casos la enfermedad vuelve a dar síntomas, ya sea en el mismo lugar, o como ocurre en múltiples ocasiones de manera contralateral. ${ }^{8}$

Hasta ahora se ha estado usando diferentes tratamientos tales

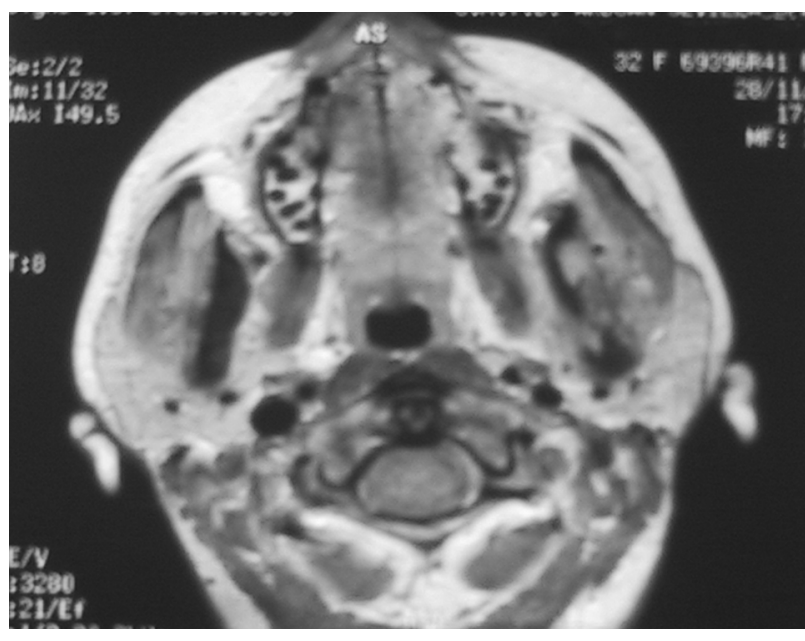

Figura 3. RM: Se aprecia la tumefacción de partes blandas alrededor de maxilar izq.

Figure 3. MRI showing swelling of soft tissue around the left maxilla.
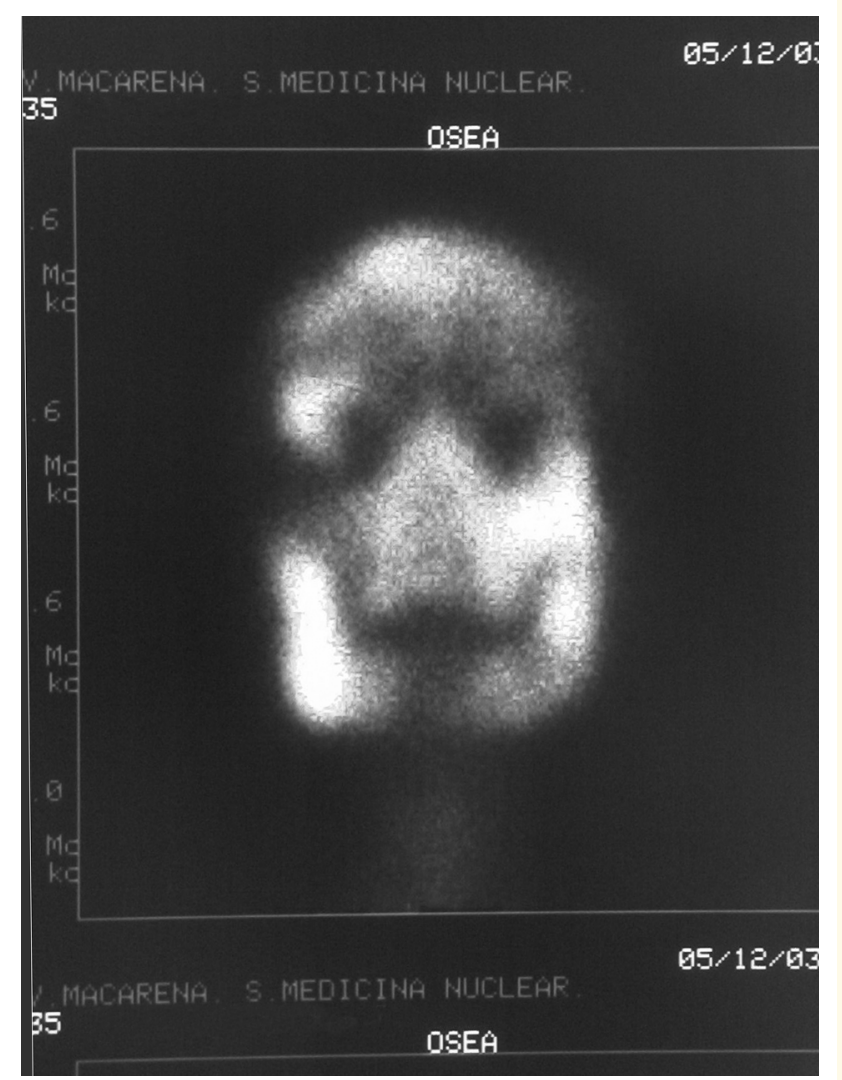

Figura 4. Gammagrafía: donde se ven zonas hipercaptantes en frontal y rama mandibular dcha, y malar y rama mandibular izq. Figure 4. GAMMA camera image showing areas with hyperconcentration in frontal bone and right mandibular ramus, and left malar and mandibular ramus. perspective but she developed mild trismus and an occlusal split was prescribed. In September 2003 she was suffering from intense pain and inflammation of the right mandibular ramus. The CAT scan revealed chronic osteomyelitis that was affecting both rami of the mandible, together with sclerotic reaction in the left half of the mandible and osteolytic reaction in the right ramus. In November 2003 she was prescribed roxithromycin $150 \mathrm{mg} / 12 \mathrm{~h}$ with amenen $30 \mathrm{mg} / 12 \mathrm{~h}$. After a month of treatment the patient reported considerable improvement in the symptoms, the control analysis showed a high C-reactive protein, normal calcium metabolism, with LDH and phosphorus increases, and normal monthly hepatic control. The control MRI scan (Fig. 3) showed sclerotic changes in the left ramus and condyle with destruction of the medial and external cortical areas, compatible with the surgical treatment, and sclerotic reaction in the right ramus by the mandibular angle with irregularities in the external cortex and inflammation of the masseter muscle and bilateral lymph node swelling. The bone scan with gamma camera (Fig. 4) showed a slight increase in the vascular phase by the right upper, external area of the orbit, left malar and right mandibular ramus. In the bone phase these was an increase in the left and right malar, and an increased uptake in the left condyle and right femur, which did not show any clinical symptoms following treatment with roxithromycin.

The patient was seen periodically. The symptoms improved considerably together with the pain in the mandible, 
como AINES, corticoides, tratamiento prolongado con terapia antimicrobiana, oxígeno hiperbárico, férula de descarga, y lo que parece haber sido más efectiva es el tratamiento quirúrgico eliminando el supuesto foco infeccioso, mediante decorticación de la zona afecta, ${ }^{9}$ pero incluso en estos casos se describe una recaída homolateral entre un $50-75 \% .{ }^{10}$

Ante la evolución de la enfermedad, y la relación que tiene según los últimos estudios con el síndrome SAPO, 3 y su comportamiento hacia los distintos tratamientos, parece que se trata de una patología de características autoinmunes, que se inicia como una infección por patógenos poco virulen-

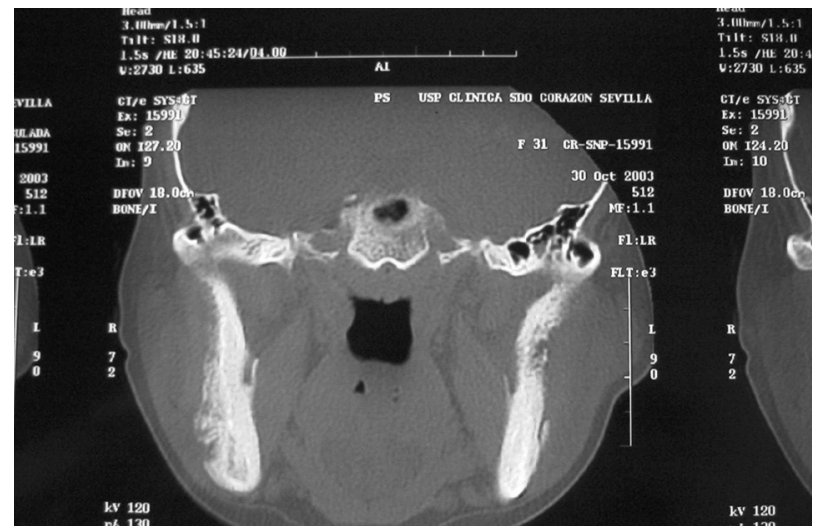

Figura 5. TAC: Afectación de ambas ramas mandibulares con reacción esclerosante rama izq. Y reacciones líticas en la dcha. Figure 5. CAT scan showing how both mandibular rami are affected, with sclerotic reaction in left ramus and lytic reaction in right ramus. tos que desencadenarían una reacción inmunológica que explicaría los hallazgos encontrados y que los cultivos tomados sean frecuentemente estériles o se aislen gérmenes de baja infectividad. ${ }^{11}$ Ante esto y siguiendo la teoría de T. Yoshii et al. ${ }^{10}$ parece que la OED se comporta como una enfermedad de biofilm, un proceso en el cual las bacterias crecen en un medio apropiado (biofilm) en el que los antimicrobianos son poco efectivos, y permiten un crecimiento bacteriano lento a pesar de las condiciones adversas, proporcionándoles una resistencia antibiótica, y su crecimiento lento, permite establecer una infección bacteriana crónica como la osteomielitis o en otros casos la bronquiolitis difusa, donde ha sido probado como efectivo el tratamiento con Roxitromicina y otros macrólidos, más que por su efecto antimicrobiano, por el efecto antiinflamatorio que poseen. La Roxitromicina parece que destruye el biofilm, inhibe la producción de varias citoquinas tales como interleukina 1-B, TNF, e interleuquina 6,12,13 todas ellas juegan un papel importante en la resorción ósea, inhibe la activación linfocitaria, la quimiotaxis de neutrófilos y estimula macrófagos para la producción de otras citoquinas beneficiosas. Este efecto se pone de manifiesto al comprobar durante el seguimiento de nuestra paciente en el estudio radiológico, como desaparecen las lesiones osteolíticas, a la vez que va desapareciendo la sintomatología, aunque las lesiones osteoescleróticas se mantienen, o incluso aparecen otras nuevas, lo cual no contradice nuestra teoría ya que estas lesiones se están considerando según los últimos estudios ${ }^{14}$ como una forma de cicatrización ósea.

El problema para nosotros, igual que para otros autores que han descrito tratamientos antibióticos a largo plazo como terapia para la OED, es saber cuánto tiempo debemos mantener el tratamiento antibiótico en estos pacientes, para que no haya nuevas recaídas. Yoshii et al10 presentan un estudio con 11 pacientes, tratados con roxitromicina durante 10-12 meses, y en todos consiguió reducción de los síntomas, y en 7 de estos pacientes desaparició por completo los mismos. Nuestra paciente ha sido tratada con roxitromicina favorablemente durante 18 meses.

El tratamiento con roxitromicina supone tener en cuenta, el que no de problemas colaterales, tales como afectación hepática, osteolytic foci. After March the patient decided to suspend the treatment as she wanted to conceive and she is to date (May 2005) asymptomatic.

\section{Discussion}

VSO treatment is complex, as many therapies have been tried without any satisfactory results in the long term. In the short term there are therapies that can eliminate the symptoms temporarily, but in many cases the symptoms of the disease return, either in the same place or, as occurs in many occasions, in a contralateral manner. ${ }^{8}$

Up until now different treatments such as NSAIDs, corticoid treatment, prolonged treatment with antimicrobic therapy, hyperbaric oxygen and occlusal splints have been used. What appears be most effective is surgical treatment to eliminate the presumed focus of infection by means of the decortication of the affected area, ${ }^{9}$ but even in these cases a homolateral relapse has been reported in $50-75 \%$ of cases. ${ }^{10}$

In view of the evolution of the disease, its relationship with $\mathrm{SAPO}^{3}$ according to recent studies, and its behavior regarding the different treatments, it appears to be a pathology with autoimmune characteristics, that starts as an infection with a low pathogen level setting off a immunological reaction. This would explain the findings, and that the cultures taken were frequently sterile, or that germs with low infectious levels were isolated. ${ }^{11}$ In view of this and following the theory of T. Yoshii et al., ${ }^{10}$ it would seem that DSO behaves as a biofilm disease, a process whereby bacteria grow in an appropriate medium (biofilm) in which the antimicrobial agents are not very effective. Slow bacterial growth is allowed despite the adverse conditions, enabling resistance to antibiotics. This slow growth allows chronic bacterial infection to be established such as osteomyelitis, or in other cases diffuse bronchiolitis for which treatment with Roxithromycin and other macrolides has proved effective, not for their antimi- 
o intolerancias de otro tipo, para lo cual hemos mantenido un seguimiento mensual repitiendo las analíticas, y hemos tenido en cuenta la evolución de la enfermedad y los tratamientos previos a los que se ha visto sometida la paciente, y con todo esto siguiendo las directrices de T. Yoshii et al. ${ }^{10}$ hemos mantenido el tratamiento con Roxitromicina durante 18 meses mejorando la paciente completamente de su sintomatología, y sin experimentar recaída alguna en las localizaciones iniciales, si bien es cierto que han aparecido focos escleróticos en otros lugares como malar y frontal, sin que hayan dado clínica, o una clínica leve, y sus analíticas han sido normales salvo una leve elevación de LDH.

Otros autores como Montonen ${ }^{9}$ abogan por la decorticación y oxígeno hiperbárico para el tratamiento, asociado al uso de antibióticos, no el uso de estos en exclusiva, y otros autores como Montes et al ${ }^{7}$ consideran que no es necesario el uso de antibióticos porque piensan que no es una enfermedad de origen infeccioso.

Ante nuestros resultados obtenidos y la evolución de la paciente, recomendamos decorticalización + roxitromicina a largo plazo como una línea de tratamiento a tener en cuenta en la OED por la eficacia que viene demostrando y los tolerables efectos secundarios, si bien cada caso debido a la complejidad de la enfermedad debe ser revisado individualmente, pero teniendo en cuenta esta opción terapéutica como primera elección.

\section{Bibliografía}

1. Groot RH, Van merkesteyn SPR, Bras J. Diffuse sclerosing osteomyelitis and florid osseous dysplasia. Oral med oral pathol oral radiol endod 1996;81:33342.

2. Marx RE, Carlson ER, Smith BR, Toraya N. Isolation of Actinomyces species and Eikenella corrodens from patients ith chronic diffuse sclerosing osteomielitis. J Oral Maxillofac. Surg 1994;52:26-33.

3. Eyrich GK, Langenegger T, Bruder E, Sailer HF, Michel BA. Diffuse chronic sclerosing osteomyelitis and the synovitis, acne pustulosis hyperostosis, osteitis (SAPHO) syndrome in two sisters. Int J Oral Maxillofc Surg 2000;29:49-53.

4. Eyrich GK, Harder C, Sailer HF, Langenegger T, Michel BA. Mandibular primary chronic osteomyelitis associated with synovitis, acne, pustulosis, osteitis (SAPHO) syndrome. J Oral Pathol Med 1999;28:456-64.

5. Eyrich GK, Baltensperger MM, Bruder E, Graetz KW. Primary chronic osteomyelitis in childhood and adolescence: a retrospective analysis of 11 cases and review of the literature. J Oral Maxillofac Surg 2003;61:561-73.

6. Van Merkesteyn JP, Groot RH, Bras J, McCarrol RS, Bakker DJ. Diffuse sclerosing osteomyelitis of the mandible: A new concept of its etiology. Oral Surg Oral Med Oral Pathol 1990;70:414.

7. Montes J, Bermudo L, Valiente A, Peyrallo F. Tratamiento de la osteomielitis esclerosante difusa mandibular con férula oclusal. Rev Esp cirug oral y maxillofac 1996;18(2):99-105.

8. Jacobsson S. Diffuse sclerosing osteomielitis of the mandible. International journal of oral surgery 1984;13:365-85.

9. Montonen M, Lizuka T, Hallikainen D, Lindqvist C. Decortication in the treatment of diffuse sclerosin ostomyelitis of the mandible. Retrospective analysis of 41 cases between 1961 and 1990). Oral Surgery oral medicine oral pathology 1993;75:5-11. crobial effect but rather for the anti-inflammatory effect they have. Roxithromycin appears to destroy biofilm; it inhibits the production of various cytokines such as interleukin 1-B, TNF and interleukin-6,12,13 that all play a very important role in bone resorption, inhibiting lymphocytic activation, chemotaxis of neutrophils, stimulating macrophages to produce other beneficial cytokines. This effect became obvious during the follow-up of our patient, as the radiologic study showed how the osteolytic lesions had disappeared at the same time as the symptoms. However, the osteosclerotic lesions remained or new ones had appeared, which does not contradict our theory as, according to the latest studies, ${ }^{14}$ these lesions are now being considered as a type of bone healing.

The problem for us and for other authors that have described long-term antibiotic treatment as a therapy for DSO, is knowing how long antibiotic treatment should be maintained for these patients, so that relapses are avoided. Yoshii et al10 presented a study with 11 patients that were treated with roxithromycin for 10-12 months and all patients showed a reduction in the symptoms, and in 7 they disappeared completely. Our patient was treated favorably with roxithromycin for 18 months.

When treatment with roxithromycin is given, it should be kept in mind that collateral problems should be avoided such as hepatic conditions, or intolerance of another sort. In view of this, we conducted a monthly follow-up to repeat tests, keeping in mind the evolution of the disease and the previous treatment the patient had been given. We followed the recommendations of $T$. Yoshii et al., ${ }^{10}$ and roxithromycin treatment was maintained for 18 months. The patient's symptoms improved completely, there was no relapse at the initial sites, although sclerotic foci did appeared in other areas such as the malar and frontal bones, without there being any clinical symptoms, or just slight symptoms, and her tests have been normal with the exception of slightly raised $L D H$.

Other authors such as Montonen ${ }^{9}$ favor decortication and hyperbaric oxygen as treatment, in conjunction with antibiotics, not just antibiotics on their own. Other authors such as Montes et al7 consider that the use of antibiotics is not necessary as they feel that it is not a disease with an infectious origin.

In view of the results obtained and the evolution of the patient, we recommend considering decortication with roxithromycin in the long term as a line of treatment for VSO, given the efficacy demonstrated and the tolerable secondary effects. Every case should, however, be reviewed individually given the complexity of the disease while taking into consideration this therapeutic option as a first choice. 
10. Yoshii T, Nishimura H, Yoshikawa T, Furudoi S, Yoshioka A, Takenono I, Ohtsuka Y, Komori T. Therapeutic possibilities of long-term roxithromycin treatment for chronic diffuse sclerosing osteomyelitis of the mandible. Journal of antimicrobial chemotherapy 2001;47: 631-7.

11. Malmström M, Fyhrquist F, Kosuren TU, Tasanen A. Inmunological featues of patients with chronic sclerosing osteomielitis of the mandible. International journal of oral Surgery 1983;12:6-13.

12. Konno S, Adachi M, Asano K, Okamoto K, Takahashi T. Inhibition of human T- lymphocyte activation by macrolide antibiotic, roxythromycin. Life Sciences 1992;51:231-6.

13. Konno S, adachi M, Asano K, Kawazoe T, Okamoto K, Takahashi T. Influences of roxithromycin on cell-mediated immune responces. Life Sciences 1992;51:107-12.

14. Roldan C, Terheyden H, Dunsche A, Kampen WU, Schroeder SO. Acne with chronic recurrent multifocal osteomyelitis involving the mandible as part of the SAPHO syndrome: case report. British Journal of oral and maxillofacial surgery 2001;39:141-4. 